\title{
Digital Simulation as a Design Method of Artificial Lighting for Prayer Rooms
}

\author{
F B Ola*1, B Michelle ${ }^{2}$ \\ ${ }^{1,2}$ Architecture Department, Universitas Atma Jaya Yogyakarta, Indonesia \\ E-mail: frengky.ola@uajy.ac.id ${ }^{1}$
}

Submitted: 26 April 2021, revised: 15 July 2021, accepted: 21 July 2021

\begin{abstract}
Abstrak. Tujuan penulisan artikel ini adalah untuk memaparkan hasil perancangan pencahayaan ruang ibadat dengan metode simulasi untuk menjawab kebutuhan fungsi dan suasana. Perancangan pencahayaan ruang ibadat pada umumnya masih belum menggunakan pendekatan terpadu. Permasalahan yang umum dihadapi ruang ibadat khususnya gereja dan/atau kapel adalah cahaya yang terlalu silau atau terlalu buram pada beberapa kasus. Hasil kegiatan pengabdian berupa perencanaan pencahayaan Gereja Santa Theresia Sedayu dan Kapel SMA de Britto dengan metode simulasi digital diharapkan dapat memberikan gambaran mendesain pencahayaan dengan metode yang lebih terukur dan dapat memenuhi kebutuhan akan suasana. Simulasi pencahayaan pada kedua kasus tersebut menggunakan perangkat lunak DIALux evo. Hasil simulasi adalah perancangan pencahayaan yang memenuhi standar pencahayaan sekaligus memberikan suasana sakral. Penyelesaian masalah pencahayaan dengan simulasi digital adalah salah satu metode untuk merancang yang lebih terukur dan dapat memenuhi kebutuhan suasana. Pengukuran lapangan hasil aplikasi desain tata cahaya dapat dilakukan untuk mengukur tingkat pencapaian dan validasi hasil simulasi.
\end{abstract}

Kata kunci: simulasi digital, ruang ibadat, tata cahaya, gereja

\begin{abstract}
This article aims to describe the results of the lighting design for the prayer room using a simulation method to answer the needs of function and ambience. In general, the lighting design for prayer rooms does not use an integrated approach. A common problem faced by prayer rooms, especially churches and chapels, is too glaring or too dim in some cases. The results of the community service activities in the form of lighting planning for the Church of Santa Theresia Sedayu and Chapel of SMA de Britto with the digital simulation method expect to provide an overview of designing lighting with a more measured method that can meet the needs of the ambience. Lighting simulation in both cases uses DIALux Evo software. The simulation result shows that the lighting design meets lighting standards and is able to provide a sacred atmosphere. Concerning the study, solving lighting problems with the digital simulation as the method is more scalable and can meet the ambience needs. Field measurements of the lighting design results can be carried out in the future to measure the simulation's level of achievement and validation.
\end{abstract}

Keywords: digital simulation, prayer rooms, lighting, church 


\section{Introduction}

The design of artificial lighting for non-profit building is still based on habits and instinct including the design of artificial lighting for churches. The planning of artificial lighting design for churches usually focuses more on building sacred nuance but does not concern the lighting standard. This can be seen on some cases in church lighting such as glare [1] and dim lighting [2]. The glaring and dim lighting may cause inconvenience for the worshipers when praying. Church lighting needs to pay attention on the functional needs (quantitative) and ambience need (qualitative). The lighting design also needs to pay attention on the standard lighting for churches [3], glorious and monumental nuance [4], the lighting colors, lighting selection, and types of lighting [5]. The compliance of the lighting needs and standards will build a solemn and peaceful mood.

Combining direct and indirect lighting can build an ambience and give suitable amount of lighting for the church's needs. Direct lighting refers to direct lighting distribution [6]. Meanwhile, indirect lighting refers the lighting that is shot to the ceiling or upper side walls and is reflected to illuminate all the room [7]. The two types of light distribution play important role in complying the standard and creating a sacred atmosphere. Regarding the situation, simulation method can be helpful to create the ambience and fulfill the functional needs. The simulation allows designers to find lighting that is not standard [8][9]. Besides that, the simulation can answer the problems of lighting by designing solution that meets the standard [10][11][12][13][14][15]. Simulation is considered to be necessary to see whether a design has complied the standard so inconvenience can be minimalized.

\section{Object Description}

The simulation objects are St. Theresia Sedayu Church and SMU Kolese de Britto Chapel, that are located in Province of D.I. Yogyakarta. The simulation of the two objects is a part of Universitas Atma Jaya Yogyakarta social service. The combination of direct and indirect lighting is used to fulfill the quantitative needs and create solemn and glorious ambience on the two objects.

\subsection{Church of Santa Theresia Sedayu}

This is a catholic church that facilitates people and administrators of the church to worship. The making of artificial lighting of this church is considering the shape of the room, the color, the lighting technique and types of the lamps, and the lighting point. The total area of the church building is \pm $1510 \mathrm{~m}^{2}$ with the ground floor area of $\pm 870 \mathrm{~m}^{2}$ and the second floor (balcony) area of $\pm 640 \mathrm{~m}^{2}$. The height of the building is $20.5 \mathrm{~m}$ with the altar height of $1.2 \mathrm{~m}$ and the altar ceiling of $3.7 \mathrm{~m}$.

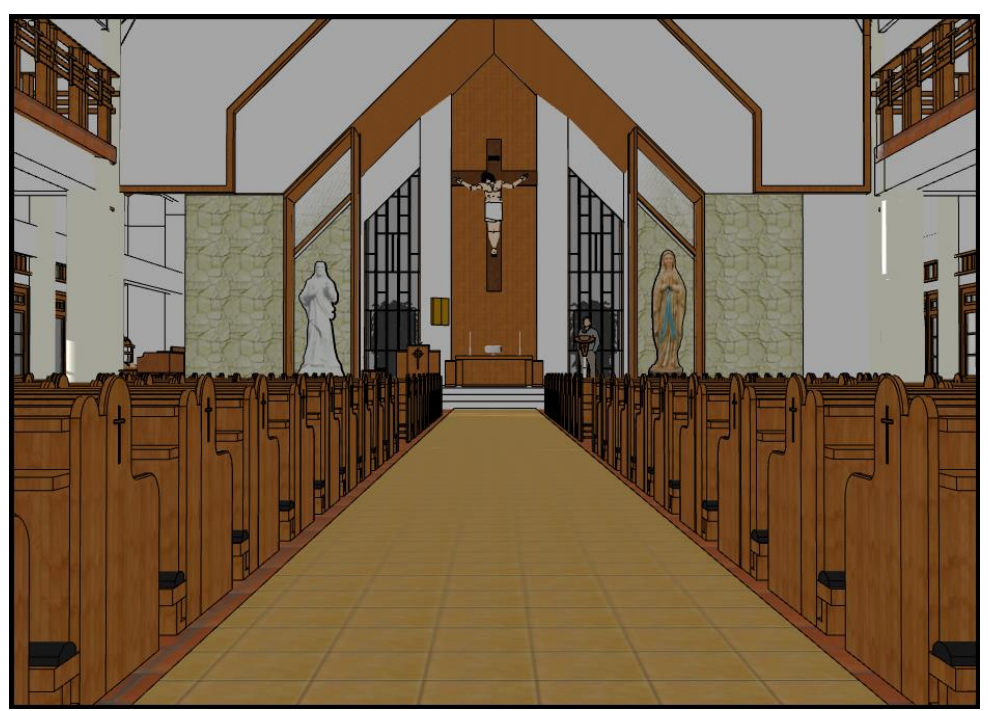

Figure 1. Interior of Santa Theresia Sedayu Church

From Figure 1, it can be seen that the church uses brown and white colors as the dominant colors. The church interior concept that blends with nature influence the dominance of the two colors 
in the room. This will affect the selection of lamp types and the power. In Table 1, it can be seen that the material plays important role in the lighting especially in terms of reflecting the light. The material of roughcast plastering white has high level of light reflection. Meanwhile, the wooden material has low level of light reflection, but it can be solved with the addition of reflective coating.

Tabel 1. Church Material and Setting DIALux Evo

\begin{tabular}{lllcccc}
\hline No & \multicolumn{1}{c}{ Types } & Position & $\begin{array}{c}\text { Reflection } \\
\text { Factor }\end{array}$ & $\begin{array}{c}\text { Reflective } \\
\text { Coating }\end{array}$ & $\begin{array}{c}\text { Degree of } \\
\text { Transmission }\end{array}$ & $\begin{array}{c}\text { Refractiv } \\
\text { e Index }\end{array}$ \\
\hline 1 & Transparent glass & Windows & 0.13 & - & 0.13 & 1.500 \\
2 & White pea wood & Ceiling, doors & 0.24 & 0.04 & - & - \\
3 & Roughcast plastering white & Columns & 0.86 & 0 & - & - \\
4 & Painted FrontCol & Walls & 0.63 & 0.39 & - & - \\
5 & Brown beige paint & Walls and ceiling & 0.07 & 0.27 & - & - \\
6 & Brown tiles & Floor & 0.40 & 0.12 & - & - \\
7 & Bamboo & $\begin{array}{l}\text { Ceiling below the } \\
\text { balcony }\end{array}$ & 0.55 & 0.76 & - & - \\
\hline
\end{tabular}

\subsection{SMA Kolese De Britto Chapel}

This chapel is a catholic prayer place to facilitate the members of SMA Kolose De Britto. The setting of the church artificial lighting considers the shape of the room, the color, the lighting technique and types of the lamps, and the lighting point. The total area of the church building is $\pm 922 \mathrm{~m}^{2}$ with the first-floor area of $\pm 700 \mathrm{~m}^{2}$ and the second floor (balcony) area of $\pm 230 \mathrm{~m}^{2}$. The height of the building is $14.50 \mathrm{~m}$ with the altar height of $0.75 \mathrm{~m}$ and the altar ceiling of $5.4 \mathrm{~m}$. Figure 2 shows that the chapel uses dominant colors of brown and white. The ceiling uses colored UPVC and wood pattern with exposed sawhorse. Yellow glass material is the compensation of the ventilation application so that the lighting level is close to the existing condition.

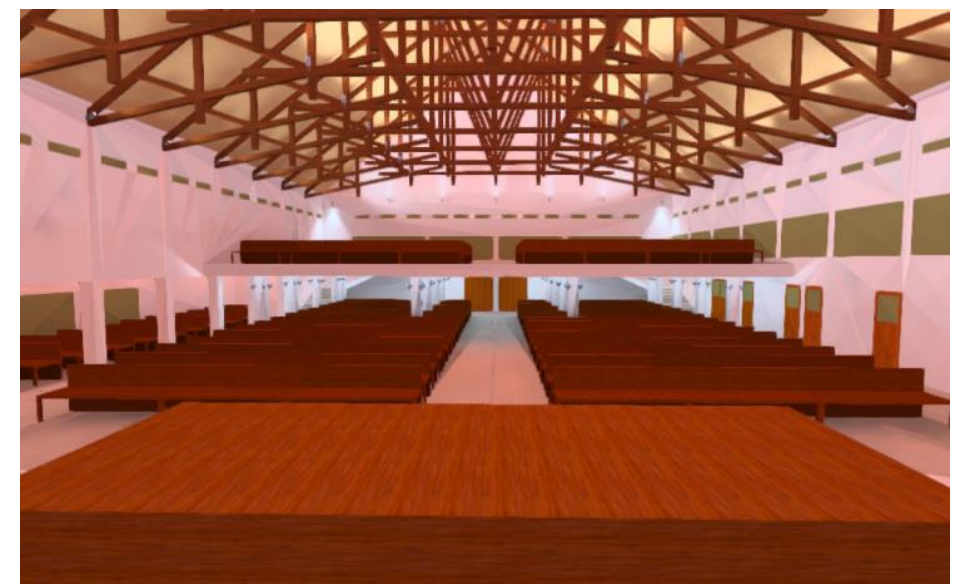

Figure 2. Interior of De Britto Chappel

Table 2 shows that the materials play important role in lighting application especially in reflecting the lights. The material of white wall has higher reflectance level. Meanwhile, UPVC material with wood pattern has low reflectance level, but it is compensated with reflective coating. 
Table 2. Chapel Material and Setting Dialux Evo

\begin{tabular}{rlccccc}
\hline No & \multicolumn{1}{c}{ Figure } & Position & $\begin{array}{c}\text { Reflection } \\
\text { Factor }\end{array}$ & $\begin{array}{c}\text { Reflective } \\
\text { Coating }\end{array}$ & $\begin{array}{c}\text { Degree of } \\
\text { Transmission }\end{array}$ & $\begin{array}{c}\text { Refractive } \\
\text { Index }\end{array}$ \\
\hline 1 & Yellow glass & Windows & 0.35 & - & 0.60 & 1.050 \\
2 & White wall paint & Walls & 0.85 & 0 & - & - \\
3 & Palisander wood & Sawhorse & 0.08 & 0.40 & - & - \\
4 & Light oak 1 wood & Floor & 0.46 & 0.04 & - & - \\
5 & Light oak 2 wood & Ceiling & 0.46 & 0.25 & - & - \\
6 & Cherry maroon wood & Chapel chair & 0.07 & 0.27 & - & - \\
\hline
\end{tabular}

\section{Method}

\subsection{Literature Study for functional and nuance need analysis}

Table 3 shows the lighting quantitative standard for prayer room based on recommended average lighting level, rendering level, and the color temperature. Calm and peaceful lighting concepts can be obtained by designing the light quantity a little lower than the standard. Quantitatively, the lighting level for the nave is designed to be 100-150 lux, while the altar area 150-200 lux. For the qualitative aspect, the design completion needs to be supported with literature studies because qualitative aspects do not have fixed standard. The literature studies are used to avoid subjective assessment.

Lights have symbolic meaning in Catholic teaching, which is the representation of Jesus Christ who dispels darkness and purifies people from sins [16]. The lighting is focused on the center of the church (nave) to the altar by displaying enlarging lighting to focus the view on the altar [17]. The fulfilment of qualitative aspects is done by differentiating the lighting quantity in the altar and the nave. Besides that, it can be also done by the application and positioning of lamp types.

Table 3. Average Lighting Level for Prayer Rooms

\begin{tabular}{|c|c|c|c|c|c|}
\hline \multirow{2}{*}{$\begin{array}{c}\text { Room } \\
\text { Functions }\end{array}$} & \multirow{2}{*}{$\begin{array}{l}\text { Lighting Level } \\
\text { (Lux) }\end{array}$} & \multirow{2}{*}{$\begin{array}{l}\text { Color } \\
\text { rendering } \\
\text { groups }\end{array}$} & \multicolumn{3}{|c|}{ Color Temperature } \\
\hline & & & $\begin{array}{c}\text { Warm white } \\
<3300 \mathrm{~K}\end{array}$ & $\begin{array}{c}\text { Cool white } \\
3300 \mathrm{~K}-5300 \mathrm{~K}\end{array}$ & $\begin{array}{c}\text { Daylight } \\
>5300 \mathrm{~K}\end{array}$ \\
\hline Mosque & 200 & 1 or 2 & & $\downarrow$ & \\
\hline Church & 200 & 1 or 2 & & $\bullet$ & \\
\hline Temple & 200 & 1 or 2 & & $\bullet$ & \\
\hline
\end{tabular}

Source: SNI 03-6197-2000

\subsection{Studies on room geometry and responses on color concept and lighting}

Geometry and room opening will affect the lighting. Square-shape rooms with square opening are optimal using LED lighting, while beam rooms with rectangle opening does not have any differences between the use of fluorescent or LED [18]. Therefore, lighting selection needs to consider the room geometry to be more effective and more energy saving. 


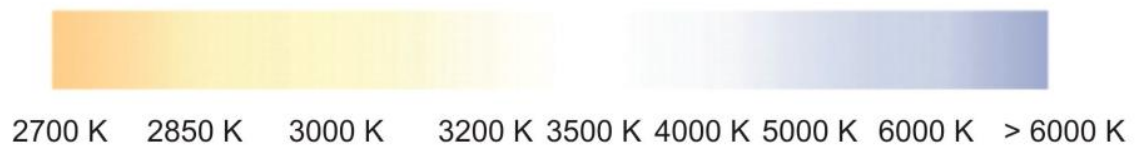

Figure 3. Light Color Temperature

Besides the choosing of lamp types, the colors of the lamps are also important to consider. The lamp color temperature is measured with the unit of Kelvin [19]. Figure 3 that is adapted from Livingston [20] shows that the higher the value, the more white-bluish (bright day lights) the color becomes, and the lower the value, the more red (sunrise/sunset) the color gets. General lighting and ambience lighting use shifting of color temperature from warm white to cool white (3000-3200 K). The value is chosen because it gives impression of magnificent, intimate but still comfortable to read.

\subsection{Studies on the selection of lighting sources (lamp types) and positioning of lighting}

According to Livingston, here are the types of lamps and the technical explanation [20]. Table 4 shows that each type of lamps have weaknesses and strengths. The lamp used here is LED lamps to minimalize the energy usage [21]. Furthermore, the lamps need low maintenance costs since lamps have longer endurance.

Tabel 4. Comparison of Lamp Types

\begin{tabular}{lllccc}
\hline \multicolumn{1}{c}{ Light Source } & Output Range & Control of Beam & $\begin{array}{c}\text { Lifetime } \\
\text { (hours) }\end{array}$ & Installment Maintenance \\
\hline Incandescent & Low & Excellent & $750-2000$ & $\$$ & $\$ \$ \$ \$$ \\
Halogen & Low to mid & Excellent & $2000-5000$ & $\$ \$$ & $\$ \$ \$$ \\
$\begin{array}{l}\text { Compact } \\
\text { Fluorescent }\end{array}$ & Mid to high & Fair & $10000-20000$ & $\$ \$ \$$ & $\$ \$$ \\
$\begin{array}{l}\text { Linear } \\
\text { Fluorescent }\end{array}$ & Mid to high & Fair & & & \\
Metal Halide & Mid to high & Good to excellent & $10000-30000$ & $\$ \$ \$$ & $\$ \$$ \\
LED & Low to high & Low to excellent & $20000-50000$ & $\$ \$ \$ \$$ & $\$ \$$ \\
\hline
\end{tabular}

Source: Livingston, 2014

The lighting concept can use the combination of direct and indirect lighting. Direct lighting is used for illuminating the activity and indirect lighting is used for giving ambience to the room. Direct lighting uses glazed lamp armature to give impression like lanterns. The aim is to produce softer lights and minimalize glare although using direct lighting. For indirect lighting, the lamps used are widespot beam so that the light can be more centralized and can reach wider area. Spotlights are used in the structure columns and the lights are directed to the center of the ceilings in order to create magnificent ambience. Besides that, indirect lighting can also use cove lighting technique. This technique can conceal the lamps from the audience' sight and glow the lights to the walls and ceilings. For the implementation, this technique uses LED strip lamps. Moreover, indirect lighting can also be used on the ceiling below the balcony with the main entrance to give peaceful and inviting ambience

\subsection{Studies on Simulation}

The lighting planning of the two prayer rooms can be classified into 4 stages such as 1) process to identify design details and concept application, 2) conceptual process of lighting technique, lamp types and position, 3) simulation process and artificial lighting simulation by considering quantitative and qualitative needs, and 4) process to create pre-design illustration concept. The focus of this 
simulation study is on the light quantity of the tracing results on the observing spots and the ambience created from rendering the design visualization. The observing spot grid is positioned $1 \mathrm{~m}$ higher than the floor area with distance of $1 \mathrm{~m}$ between spots. The simulation is conducted using night-time scenario.

\subsection{Result Analysis Method}

Result analysis is conducted by comparing the results of design model simulation with the quantitative lighting standard and literature studies about lighting quality aspects. The best dominant value will be taken as the best design solution that will be used as the recommendation for improving the existing design, which later is made into schematic design pictures and 3D visualization.

\section{Results and Discussion}

\subsection{Simulation of St Theresia Sedayu Church}

The result of the simulation (Figure 4), which was obtained from DIALux Evo software, shows the light dispersion in the first-floor nave and the balcony has met the eye sensitivity standard of Indonesian, which is 50 lux [23]. The simulation result (Table 5) shows the highest lighting in the altar and gamelan (a set of Javanese traditional music instruments) area is close to 200 lux. The other areas have the average of 150 lux. The lighting is focused on the altar and gamelan area because the gamelan area needs lighting qualitatively while the altar area needs qualitative and quantitative lighting. For other areas, the lighting is dimmer compared to the altar area in order to create magnificent ambience of the altar.
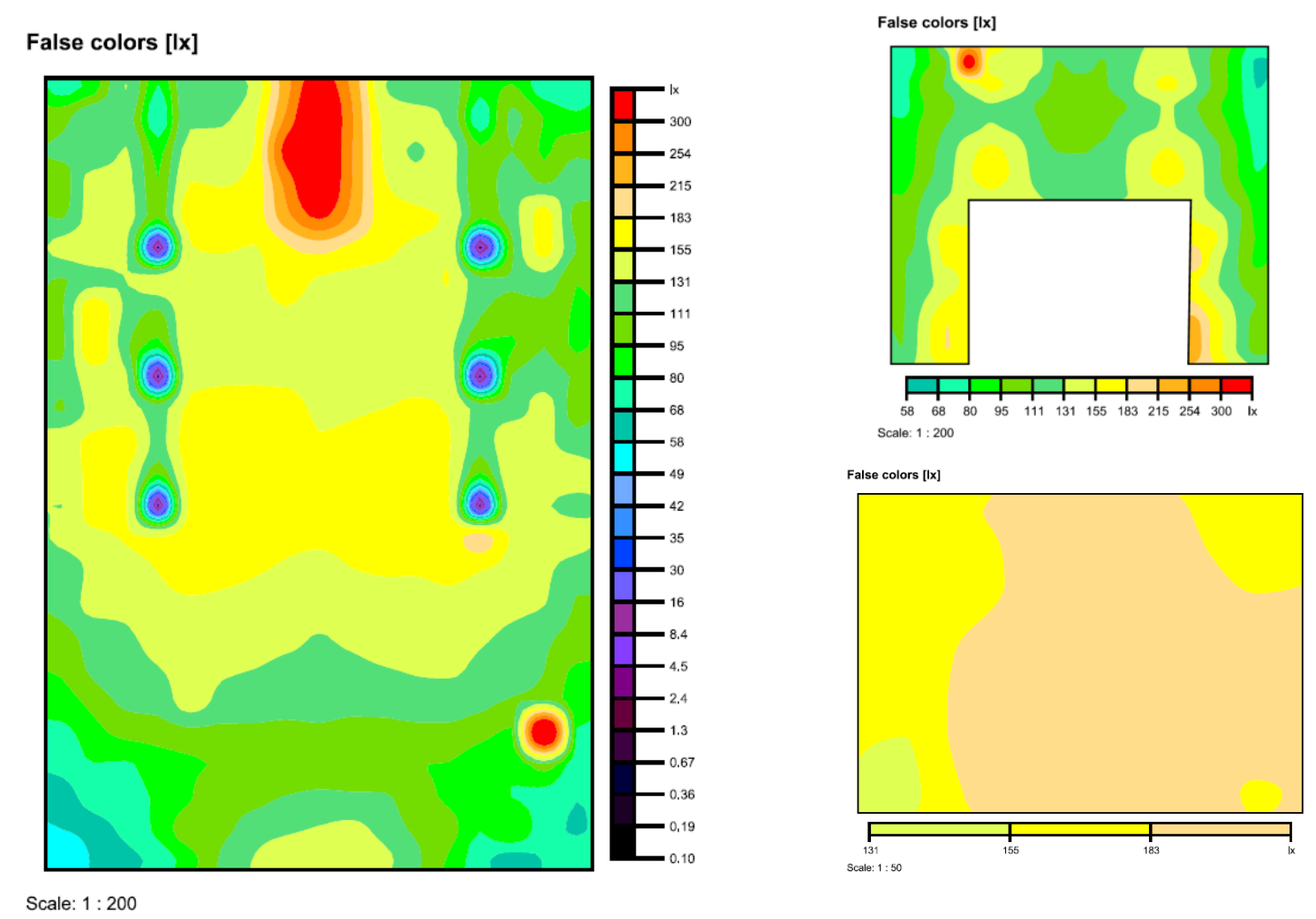

Figure 4. Simulation Result based on DIALux evo of the first floor (left), Balcony (upper right), altar area (lower right) 
Table 5. Average Result of Brightness Level based on the Rooms

\begin{tabular}{llccc}
\hline Surface & \multicolumn{1}{c}{ Results } & $\begin{array}{c}\text { Average } \\
\text { (Target) }\end{array}$ & Min & Max \\
& \multicolumn{1}{c}{\begin{tabular}{l}
\multicolumn{1}{c}{ Merpendicular illuminance [1x] } \\
Nave
\end{tabular}} & 132 & 0.006 & 427 \\
Altar Area & $\begin{array}{l}\text { Peight: } 1.00 \mathrm{~m} \\
\text { Perpendicular illuminance [1x] }\end{array}$ & 187 & 151 & 210 \\
Gamelan Area & $\begin{array}{l}\text { Height: } 1.50 \mathrm{~m} \\
\text { Perpendicular illuminance [1x] }\end{array}$ & 186 & 140 & 217 \\
Balcony Area & $\begin{array}{l}\text { Peight: } 1.30 \mathrm{~m} \\
\text { Perpendicular illuminance [1x] } \\
\text { Height: } 4.50 \mathrm{~m}\end{array}$ & 125 & 67.2 & 335 \\
\hline
\end{tabular}

Table 6. Lighting of St Theresia Sedayu Church

\begin{tabular}{|c|c|c|c|}
\hline Quantity & Luminaire (Luminous emittance) & Lamp Type & Light dispersion \\
\hline 51 & $\begin{array}{l}\text { Philips - BN132C PSU L1200 } 1 \text { xLED12S/840 } \\
\text { Lamp luminous flux: } 1250 \mathrm{~lm} \\
\text { Power: } 14.0 \mathrm{~W} \\
\text { Colorimetric data } \\
\text { 1xLED12S/840/-: CCT } 3000 \mathrm{~K}, \text { CRI } 100\end{array}$ & & \\
\hline 15 & $\begin{array}{l}\text { Philips - DN130B D } 217 \text { 1xLED20S/840 } \\
\text { Lamp luminous flux: } 2500 \mathrm{~lm} \\
\text { Power: } 22.0 \mathrm{~W} \\
\text { Colorimetric data } \\
\text { 1xLED20S/840/-: CCT } 3000 \mathrm{~K}, \text { CRI } 100\end{array}$ & & \\
\hline 40 & $\begin{array}{l}\text { Philips - ST320T } 1 \text { xLED } 39 \mathrm{~S} / 827 \mathrm{VWB} \\
\text { Lamp luminous flux: } 3750 \mathrm{~lm} \\
\text { Power: } 31.5 \mathrm{~W} \\
\text { Colorimetric data } \\
\text { 1xLED39S/ } 827 / \text {-: CCT } 3000 \mathrm{~K}, \text { CRI } 100\end{array}$ & & \\
\hline 4 & $\begin{array}{l}\text { Philips - WL131V PSU D } 4801 \text { xLED34S/840 } \\
\text { Lamp luminous flux: } 3400 \mathrm{~lm} \\
\text { Power: } 38.0 \mathrm{~W} \\
\text { Colorimetric data } \\
\text { 1xLED34S/840/-: CCT } 3000 \mathrm{~K}, \text { CRI } 100\end{array}$ & & \\
\hline 12 & $\begin{array}{l}\text { Philips - WL131V PSU D } 4801 \text { xLED } 34 \mathrm{~S} / 840 \\
\text { Lamp luminous flux: } 9001 \mathrm{~lm} \\
\text { Power: } 90.0 \mathrm{~W} \\
\text { Colorimetric data } \\
\text { 1xLED } 34 \text { S/840/-: CCT } 3000 \mathrm{~K}, \text { CRI } 100\end{array}$ & & \\
\hline
\end{tabular}




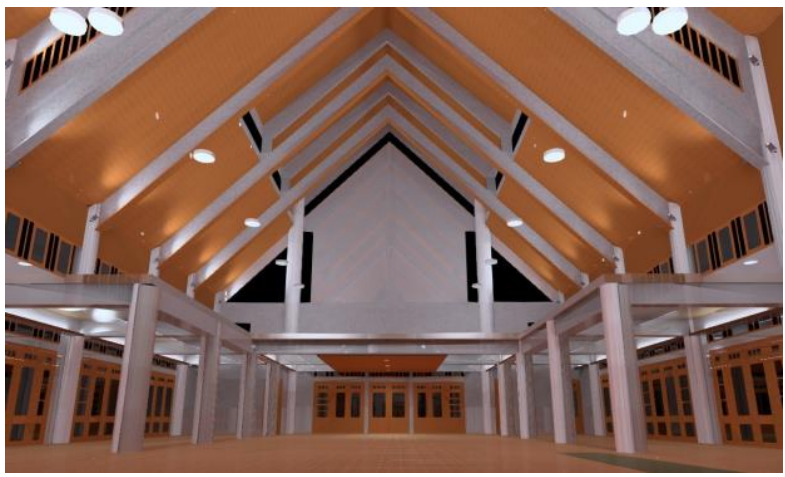

(a)

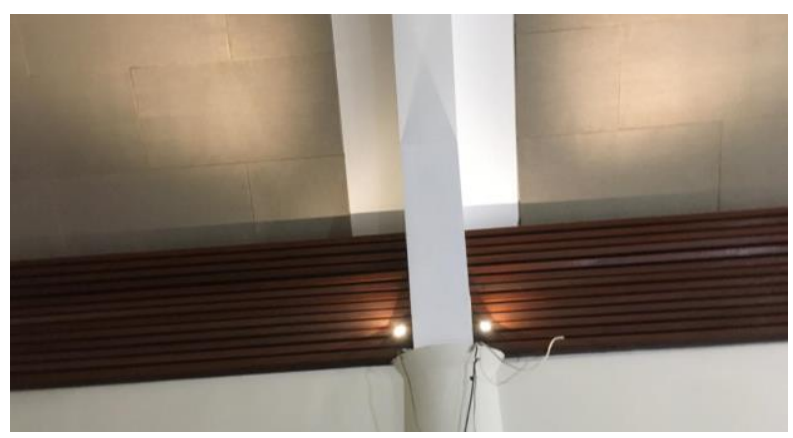

(c)

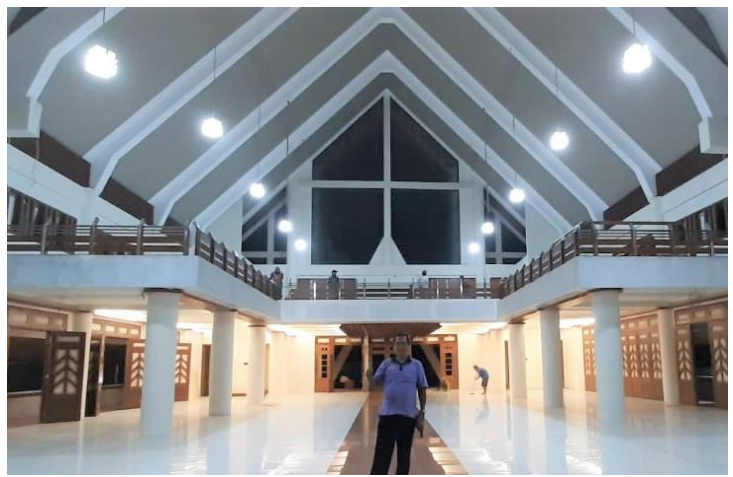

(b)

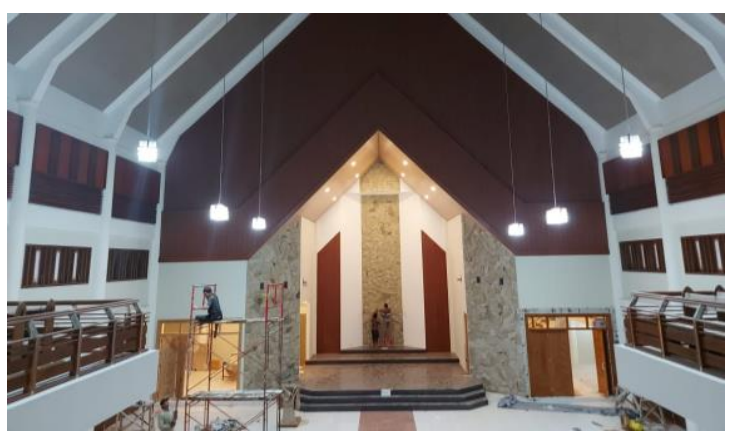

(d)

Figure 5. (Clockwise) Dialux EVO rendering results, visual from altar perspective, visual of balcony to altar perspective (some lamps have not been installed), spotlight to ceiling for the magnificent nuance and as the ambience light

Table 6 shows the total of lamp luminous flux as $372850 \mathrm{~lm}$, the total of luminaire luminous flux as $369812 \mathrm{~lm}$, total load of $3536.0 \mathrm{~W}$, and luminous efficacy as $104.6 \mathrm{~lm} / \mathrm{W}$. The lamp types affect the energy needed for the lighting. LED lamps is more effective compared to fluorescent and light bulbs because LED lamps emit the least energy and produce high intensity of lighting [22]. The lamps used for general lighting are mostly Philips - BN132C PSU L1200 1 xLED12S/840 with 51 lamps with tube shape and Philips - ST320T 1 xLED39S/827 VWB as many as 40 lamps as the spotlight. The combination of general lighting and spotlight is aimed to create the ambience that focuses on the altar with high intensity of lighting in this area.

\subsection{Lighting Simulation of De Britto Chapel}

The simulation results (Figure 6) obtained from DIALux Evo software shows that the light dispersion in the church complies SNI 03-6197-200 concerning the average lighting level as much as 200 lux. The highest light intensity is in the altar area considering the liturgical activity is focused here. The simulation results from DIALux Evo (Table 7) shows that on the nave area the average lighting level is around 100-150 lux. On the altar, the average lighting level is 200 lux in order to show function affirmation and attract the people's visual focus. The material selection affects the light reflection in the room, while the types and the amount of the lighting affects the quantity of the lighting. The three elements play important roles in deciding the standardized lighting. 
Table 7. Result of Average Lighting Level based on the Area

\begin{tabular}{llccc}
\hline Surface & \multicolumn{1}{c}{ Results } & $\begin{array}{l}\text { Average } \\
\text { (Target) }\end{array}$ & Min Max \\
\hline Ground floor and Altar & $\begin{array}{l}\text { Perpendicular illuminance [1x] } \\
\text { Tinggi: } 1.70 \mathrm{mtr}\end{array}$ & 155 & 73.4 & 262 \\
Balcony & $\begin{array}{l}\text { Perpendicular illuminance [1x] } \\
\text { Tinggi: 4.20 } \mathrm{mtr}\end{array}$ & 138 & 81 & 197 \\
Altar & $\begin{array}{l}\text { Perpendicular illuminance [1x] } \\
\text { Tinggi: 2.65 } \mathrm{mtr}\end{array}$ & 249 & 69.6 & 339 \\
\hline
\end{tabular}
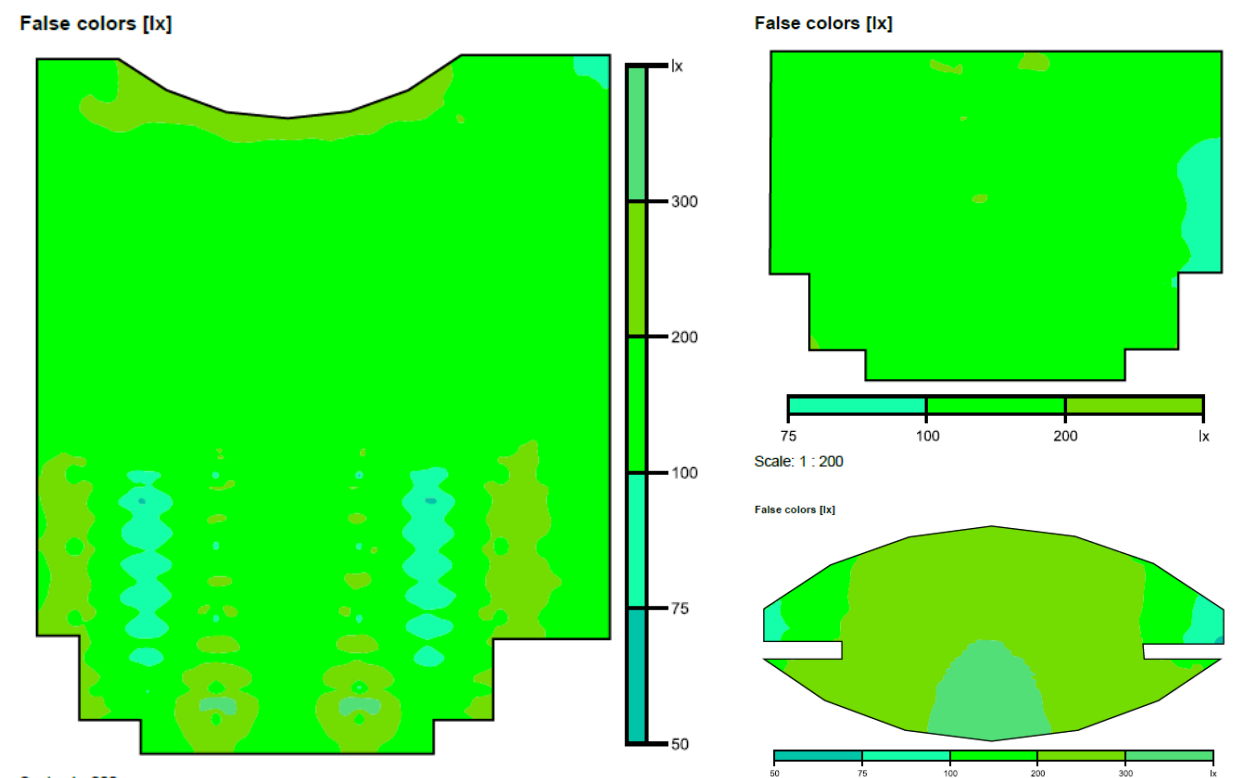

Scale: $1: 200$

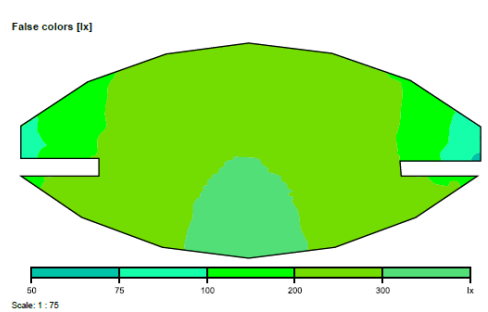

Figure 6. Simulation results for the chapel, ground floor (left), balcony (upper right) and altar (lower right)

Table 8. Lighting of De Britto Chapel

\begin{tabular}{|c|c|c|c|}
\hline Quantity & Luminaire (Luminous emittance) & Lamp Types & Dispersion \\
\hline 3 & $\begin{array}{l}\text { Philips - DN130B D165 1xLED10S/840 } \\
\text { Lamp luminous flux: } 1300 \mathrm{~lm} \\
\text { Power: } 11.6 \mathrm{~W} \\
\text { Colorimetric data } \\
\text { 1xLED10S/840/-: CCT } 3000 \mathrm{~K}, \text { CRI } 100\end{array}$ & & \\
\hline 20 & $\begin{array}{l}\text { Philips - ST315T PSU } 1 \text { xLED27S/PW930 FR60 } \\
\text { Lamp luminous flux: } 2700 \mathrm{~lm} \\
\text { Power: } 28.5 \mathrm{~W} \\
\text { Colorimetric data } \\
\text { 1xLED27S/PW930/-: CCT } 3000 \mathrm{~K}, \mathrm{CRI} 100\end{array}$ & & \\
\hline
\end{tabular}




\begin{tabular}{|c|c|c|c|}
\hline Quantity & Luminaire (Luminous emittance) & Lamp Types & Dispersion \\
\hline 104 & $\begin{array}{l}\text { Philips - ST320T } 1 \text { xLED39S/827 VWB } \\
\text { Lamp luminous flux: } 3750 \mathrm{~lm} \\
\text { Power: } 31.5 \mathrm{~W} \\
\text { Colorimetric data } \\
\text { 1xLED39S/827/-: CCT } 3000 \mathrm{~K}, \mathrm{CRI} 100 \\
\text { Philips - ST730T } 1 \text { xLED12S/827 WB } \\
\text { Lamp luminous flux: } 650 \mathrm{~lm} \\
\text { Power: } 10.5 \mathrm{~W} \\
\text { Colorimetric data } \\
\text { 1xLED12S/827/-: CCT } 3000 \mathrm{~K}, \mathrm{CRI} 100\end{array}$ & & \\
\hline
\end{tabular}

According to Table 8, the total luminous flux lamp is $493400 \mathrm{~lm}$, total luminaire luminous flux $493784 \mathrm{~lm}$, total load $4615.8 \mathrm{~W}$, and luminous efficacy $107.0 \mathrm{~lm} / \mathrm{W}$. The lamps used here are mostly Philips - ST320T 1 xLED39S/827 VWB with the total of 104 pieces as spotlight lamps. Most of the lamps are spotlight lamps and only three are downlight lamps (Philips - DN130B D165 1xLED10S/840). Indirect spotlight lamps are widely used in order to produce balanced lighting and prevent glare since the lightings are directed to the ceiling. As the result, the audience receives reflection lights. The lighting perceived by the audience is the reflection lighting, so it is comfortable for the audience. The balanced and even lighting in the observing area can be seen in Figure 6 .

\section{Conclusion}

Lighting design for churches are important to create sacred atmosphere and to meet the lighting need standard. In St Theresia Sedayu Church, the simulation results show that in general the lighting has met the standard of Indonesian eye-sensitivity of 150 lux and the areas that still need more details in lighting are altar area and gamelan area as much as 200 lux. For De Britto Chapel, the simulation shows that the light dispersion meets the standard of SNI 03-6197-200 concerning lighting level for altar area as 200 lux and the eye-sensitivity standard of Indonesian for the nave area as 100-150 lux. The concept of solemn and peaceful lighting can be obtained by designing the light quantity a little lower to the standard without putting aside the eye-sensitivity standard of Indonesian.

On both objects, the altar lighting has the highest lighting intensity among other areas. The reason is that the focus of the mass takes place in the altar. Besides that, light is the symbol of Jesus Christ's presence in the mass. The application of direct and indirect lamps can produce quantitatively sufficient lighting and magnificent, peaceful, and inviting ambience in the rooms. The material selection, lighting position, lighting types, lighting colors, and the lighting amount will affect the quantity and quality of the lightings.

The simulation method helps plan the artificial lighting for prayer rooms. This method gives confidence to planner to set the system, material, and lighting. Moreover, the method also helps planners and executors coordinate in building process, especially in the lamp instalment and the construction process. The validation of the simulation result can be done after the construction process is completed. This process is important to see the weakness of the simulation process or the used software. The future improvement in digital simulation process can be done based on the validation process.

\section{Acknowledgement}

This social service is supported by LPPM Universitas Atma Jaya Yogyakarta, year 2019/2020. The authors also express gratitude to development committee and the Priest of St Theresia Sedayu Church, and Renovation Team of SMA Kolose De Britto Chapel. 


\section{References}

[1] J. D. Intan and L. S. Arifin, "Pengaruh Pembukaan Daylighting Simbolik Terhadap Kenyamanan dan Persepsi Jemaat di Gereja," J. eDIMENSI Arsit., vol. 7, no. 1, pp. 673-680, 2019, [Online]. Available: http://publication.petra.ac.id/index.php/teknikarsitektur/article/view/9324/8405.

[2] D. S. M. Santoso, "Pengaruh Gaya Desain Gotik dan Kolonial Belanda Terhadap Efek Pencahayaan Alami pada Gereja Katolik Hati Kudus Yesus di Surabaya," Dimens. Inter., vol. 12, no. 1, pp. 16-22, 2014, doi: 10.9744/interior.12.1.16-22.

[3] S. J. Pelealu, Sangkertadi, and J. O. Waani, "Pencahayaan Buatan dalam Gereja Katolik," J. Arsit. DASENG, vol. 6, no. 1, pp. 53-62, 2017, [Online]. Available: https://ejournal.unsrat.ac.id/index.php/daseng/article/view/16766.

[4] A. C. A. Petriana, M. Wibowo, and S. M. Frans, "Perancangan Interior Gereja Bethany di Malang," J. INTRA, vol. 6, no. 2, pp. 504-518, 2018, [Online]. Available: http://publication.petra.ac.id/index.php/desain-interior/article/view/7314/6629.

[5] D. A. N. Annisa and K. K. Lestari, "Pengaruh Pemilihan Jenis dan Warna Pencahayaan pada Suasana Ruang Serta Kesan Pengunjung Kafe," Sinektika J. Arsit., vol. 18, no. 1, pp. 78-84, 2021, doi: 10.23917/sinektika.v18i1.13325.

[6] Irwansyah, "Analisis Tata Pencahayaan Interior Wildlife Museum \& Gallery Rahmat Inernasional di Medan," J. Proporsi, vol. 4, no. 1, pp. 50-61, 2018, doi: 10.22303/proporsi.4.1.2018.50-61.

[7] M. S. Kristian, Leonardo, and E. A. Halim, "Pengaruh Cara Distribusi Pencahayaan Buatan Pada Kenyamanan Bercengkerama Pengunjung Kafe," Serat Rupa J. Des., vol. 2, no. 2, pp. 148-162, 2018, doi: 10.28932/srjd.v2i2.776.

[8] E. Setyaningsih, J. Pragantha, and R. A. Mangkuto, "Simulasi Pencahayaan Terowongan Tomang Siang Hari Menggunakan Lampu LED," TESLA J. Tek. Elektro, vol. 20, no. 1, pp. $7-$ 15, 2018, doi: 10.24912/tesla.v20i1.2815.

[9] S. S. Azmi and W. Iyati, "Tata Cahaya Alami Gedung Layanan Bersama Universitas Brawijaya Malang," J. Mhs. Jur. Arsit., vol. 6, no. 3, pp. 1-9, 2018, [Online]. Available: http://arsitektur.studentjournal.ub.ac.id/index.php/jma/article/view/647/565.

[10] A. Hangga, A. M. Nisa, D. Pratama, and M. Apriliyanto, "Simulasi Pencahayaan Buatan untuk Ruang Kelas dengan Tipe Armature TL LED dan Bohlam LED," J. Tek. Elektro, vol. 11, no. 2, pp. 61-66, 2019, doi: 10.15294/jte.v11i2.26902.

[11] Atthaillah, S. Wijayanti, and S. M. Hassan, "Simulasi Desain Fasad Optimal Terhadap Pencahayaan Alami Pada Gedung Prodi Arsitektur Universitas Malikussaleh," EMARA Indones. J. Archit., vol. 4, no. 1, pp. 21-29, 2018, doi: 10.29080/emara.v4i1.228.

[12] C. N. Ayum and W. Iyati, "Tata Cahaya Ruang Dalam Perpustakaan Proklamator Bung Karno Blitar," J. Mhs. Jur. Arsit., vol. 6, no. 3, pp. 1-8, 2018, [Online]. Available: http://arsitektur.studentjournal.ub.ac.id/index.php/jma/article/view/586/523.

[13] C. Susilawati and E. N. Yulita, "Tata Cahaya pada Ruang Baca Balai Perpustakaan Grhatama Pustaka Yogyakarta," J. Mhs. Jur. Arsit., vol. 6, no. 1, pp. 1-10, 2018, [Online]. Available: http://arsitektur.studentjournal.ub.ac.id/index.php/jma/article/view/509/480.

[14] Fathimah, J. Thojib, and M. S. Adhitama, "Rekayasa Tata Cahaya Alami pada Ruang Laboratorium (Studi Kasus: Fakultas Teknik Universitas Brawijaya)," J. Mhs. Jur. Arsit., vol. 5, no. 1, pp. 1-9, 2017, [Online]. Available: http://arsitektur.studentjournal.ub.ac.id/index.php/jma/article/view/326/314.

[15] A. Mandala, "Desain Ruang dan Pencahayaan Buatan untuk Mendukung Suasana Kontemplasi pada Gereja Katolik Regina Caeli, Jakarta," ATRIUM, vol. 1, no. 2, pp. 181-195, 2015, doi: 10.21460/atrium.v1i2.48.

[16] G. Małgorzata and S. Dorota, "Some Aspects of Artificial Lighting in Churches," 2003. http://lumen.iee.put.poznan.pl/luxjunior/Gorczewska-Ilm2003.pdf (accessed Feb. 26, 2021).

[17] D. Holmes, Lighting for the Built Environment: Places of Worship. Lavenham, UK: The Lavenham Press, 2014. 
[18] T. de Rubeis, I. Nardi, M. Muttillo, S. Ranieri, and D. Ambrosini, "Room and window geometry influence for daylight harvesting maximization - Effects on energy savings in an academic classroom," Energy Procedia, vol. 148, pp. 1090-1097, 2018, doi: 10.1016/j.egypro.2018.08.050.

[19] F. Tanumihardjo, "Pemahaman Pengaturan Warna Pada Foto Interior Pengaturan White Balance di Kamera pada foto ruangan," J. Vis., vol. 12, no. 2, pp. 19-27, 2017, doi: 10.24912/jurnal.v12i2.2124.

[20] J. Livingston, Designing With Light: The Art, Science and Practice of Architectural Lighting Design. Hoboken, NJ: John Wiley \& Sons, Inc., 2014.

[21] S. Anisah and A. D. Tarigan, "Efektivitas Pemamfaatan Lampu Penerangan Hemat Energi pada Rumah Tinggal Masyarakat," JESCE, vol. 3, no. 2, pp. 82-93, 2020, doi: 10.31289/jesce.v3i2.3270.

[22] B. B. Agam, Yushardi, and T. Prihandono, "Pengaruh Jenis dan Bentuk Lampu terhadap Intensitas Pencahayaan dan Energi Buangan Melalui Perhitungan Nilai Efikasi Luminus," $J$. Pendidik. Fis., vol. 3, no. 4, pp. 384-389, 2015, [Online]. Available: http://jurnal.unej.ac.id/index.php/JPF/article/view/1435.

[23] A. Mandala, "Lighting Quality In The Architectural Design Studio (Case Study:Architecture Design Studio at Universitas Katolik Parahyangan, Bandung, Indonesia)," IOP Conf. Ser. Earth Environ. Sci, vol. 238, p. 12032, 2019, doi: 10.1088/1755-1315/238/1/012032. 